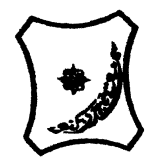

Bayero Journal of Pure and Applied Sciences, 12(1); 407 - 411

ISSN $2006-6996$

\title{
ANTIMICROBIAL ACTIVITY AND PHYTOCHEMISTRY OF METHANOLIC STEM BARK EXTRACT OF Melia azedarach (Linn.)
}

\author{
Ahmed, M., Bukar, A. H., Amuda, M.Y. and Babagana, A. \\ Kashim Ibrahim College of Education, Maiduguri, Nigeria \\ Corresponding author: matawalliahmad@gmail.com
}

\begin{abstract}
The use of traditional medicine is increasing and gaining popularity throughout the developed and developing countries. About $80 \%$ of the people in developing countries rely on traditional medicine for primary health care. The present study was carried out to evaluate the phytochemical constituents and antimicrobial activity of the stem bark of Melia azedarach extracted using methanol as solvent. Phytochemical screening revealed that methanolic stem bark extract contain alkaloid, cardiac glycoside, flavonoids, saponins, steroid, tannin and terpenoid. Antimicrobial efficiency were tested against four human pathogens: Staphylococcus aureus, Escherichia coli, Pseudomonas aeruginosa and Streptococcus spp. The diameter of zone of inhibition (ZOI) was measured and it was found that the extract showed a maximum zone of inhibition against Gram negative and Gram positive pathogens and the zone of inhibition was found to be concentration dependent. The result obtained in this study may be indication that alcoholic extracts of this plant could be a possible source of obtaining new and effective herbal medicine to treat infections which justify the ethno medicinal uses of Melia azedarach against infectious diseases agents.
\end{abstract}

Key words: Melia azedarach, antimicrobial, activity, traditional medicine, extract

\section{INTRODUCTION}

The use of traditional medicine is increasing and gaining popularity throughout the developed and developing countries (Zhang, 2005). Herbal medicines and the finished labelled medicinal product that contains active ingredients include aerial and underground parts of the plant or other plant material or combination. Medicinal plants provide accessible and culturally relevant sources of primary health care to a majority of the world's human population (Ji et al., 2009). A part from wild plants, cultivated spices and condiments are routinely used in traditional medicines (Gahukar, 2011). Medicinal plants also play an important role in maintaining biodiversity in forests, fallow and cultivated lands (Abbasi et al., 2011). Though with modern technology, indoor cultivation (glasshouses, greenhouses, Polyhouses) has become popular.

Melia azedarach is among one of the important traditional medicinal plants of South Asia region (Iran, India and south China). The name of the plant derived from Greek word "Melia" means "the ash" and the specific name comes from Persian "azzadirackt" mean noble tree. Melia azedarach is a round, deciduous, shade tree, reaching 30 to 40 feet at maturity and growing five to ten feet during the first and second year after seed germination. Growth slows as the tree reaches 15 or 20 feet tall. It is successfully grown in a wide variety of situations, including alkaline soil where other trees might fail. Bole fluted below when old, up to 30-60 (max. 1200) $\mathrm{cm}$ in diameter, with a spreading crown and sparsely branched limbs. Bark is smooth with greenish-brown when young, it is turning grey and fissured with age. Leaves alternate, 20-40 $\mathrm{cm}$ long, bipinnate or occasionally tripinnate, leaflets $3-1$, serrate and with a pungent odour when crushed. The plant consists of various biologically active compounds such as terpenoids, flavonoids, steroids, alkaloids, saponins, tannins, anthraquines (Suresh et al., 2008). The oil is the most active medicinal product of this plant. It is used as antiseptic for sores and ulcer that show no tendency to heal. It is also used for rheumatism and skin diseases such as ringworm and scabies. Internally the oil is useful in malaria fever and leprosy. Powdered dust of fruit, crude extract from wood and bark and oil is insecticidal as well as antibacterial. Alcoholic extract of the leaf is antihelminthic and mild anagestic whereas alcoholic extract of stem and bark show anticancerous, antipalmodic and antiviral property (Ramya et al., 2009). Root showed the presence of terpenoids and Limonoids like 6-Acetoxy-7-hydroxy-3-oxo 14beta, 15beta-epoxymeliac-15-diene, 6-Aceto3beta-hydroxy-7-oxo 14beta, Azecine-1, Azecine-2, Azecine-3, and Azecine-4 (Bharat, 2015). 
Special Conference Edition, November, 2019

The present study is conducted to evaluate the phytochemical constituents and antibacterial activity of methanolic stem bark extract of Melia azedarach (Linn).

\section{MATERIALS AND METHODS}

\section{Sample Collection and Preparation}

Fresh stem barks of Melia azedarach used in this study were collected from the Faculty of Agriculture, Usmanu Danfodiyo University, Sokoto Nigeria. The plant sample (Voucher number UDUT/ANS/0040) was authenticated at the Herbarium unit, Department of Biological Sciences Usmanu Danfodiyo University, Sokoto. The fresh sample of the stem bark was dried under shade for two weeks and the dried sample was pulverized with mortar and pestle and sieved with a mesh in to fine powder. The powdered sample was then kept in a polythene bag for subsequent analysis.

\section{Extraction}

The powdered stem bark $(200 \mathrm{~g})$ was extracted with methanol using soxhlet extractor for six hours using $400 \mathrm{~cm}^{3}$ of the solvents. The extract was concentrated over water bath. Percentage recovery of extract was calculated using equation 1.1

$\%$ recovery $=\frac{W 1-W 0}{M} \times 100$

$\mathrm{W}_{1}=$ Weight of extract and beaker

$\mathrm{W}_{0} \quad=\quad$ Weight of empty beaker

$\mathrm{M} \quad=\quad$ Weight of dried sample

\section{Phytochemical Analysis}

The extract was screened for the presence of alkaloids, tannins, terpenoid, saponins, flavonoids, glycosides, steroids and anthraquinones using the following methods.

\section{Test for Alkaloids}

The plant material $(0.5 \mathrm{~g})$ was stirred with $5 \mathrm{~cm}^{3}$ of $1 \%$ hydrochloric acid on a steam bath for 20 minutes, the extract was allowed to cooled and filtered. The filtrate was used for the following test.

(a) Meyer's Test

Two drops of Mayer's reagent was added to 1 $\mathrm{cm}^{3}$ of the extract. Formation of a creamy precipitates indicate the presence of alkaloids in all the extracts.

(b)Wagner's Test

To $1 \mathrm{~cm}^{3}$ of the extract two drops of Wagner's reagent was added, the formation of reddish brown precipitate indicates the presence of alkaloid (Trease and Evans, 1989).

\section{Test for Anthraquinones}

Borntrager's Test

The plant material $(5.0 \mathrm{~g})$ was boiled with 10 $\mathrm{cm}^{3}$ concentrated tetraoxosulphate (VI) acid and filtered while hot, the filtrate was shaken with 3 $\mathrm{cm}^{3}$ of chloroform. The chloroform layer was pipetted into another test tube and $1 \mathrm{~cm}^{3}$ of dilute ammonia was added. The formation of cherry red colour indicates the presence of anthraquinones (Ayoola et al., 2008).

\section{Test for Flavonoids}

(a) Sodium hydroxide Test

The extract $(2.0 \mathrm{~g})$ was dissolved in a small amount of water (drop). $1 \mathrm{~cm}^{3}$ of $10 \% \mathrm{NaOH}$ was added to $2 \mathrm{~cm}^{3}$ of the extract. Formation of a yellow colouration in each extract tested indicated the presence of the flavonoids (Trease and Evans, 1989).

b) Lead acetate Test:

The extract $(2.0 \mathrm{~g})$ was treated with few drops of lead acetate solution. Formation of yellow colour precipitate indicates the presence of flavonoids.

\section{Test for Cardiac Glycosides}

Keller-Kilianis' Test

The extract $(2.0 \mathrm{~g})$ was dissolved in $5 \mathrm{~cm}^{3}$ of water, $2 \mathrm{~cm}^{3}$ of glacial acetic acid containing 1 drop of Iron (iii) chloride solution was added, and the formation of brown ring at the interface indicates the presence of deoxysugar characteristics of cardinalities. A violet ring appeared below the brown ring while in the acetic acid layer a greenish colour formed above the brown ring which gradually spreads indicates the presence of cardiac glycosides.

\section{Test for Saponins}

Frothing Test

The extract $(0.5 \mathrm{~g})$ was dissolved in $5 \mathrm{~cm}^{3}$ of distilled water in a separate test tube. The solution was shaken vigorously and observed for persistent froth, the frothing were mixed with 3 drops of olive oil and vigorously shaken after which it was observed the formation of emulsion (Makkar, 1993).

\section{Test for Steroids}

Salkowski's Test

Concentrated $\mathrm{H}_{2} \mathrm{SO}_{4}$ (5 drops) was added to $1 \mathrm{~g}$ of the extract, the formation of reddish brown ring at the interphase indicates the presence of the steroids (Harbone, 1998).

\section{Test for Tannins}

Ferric chloride test

The extract $(0.5 \mathrm{~g})$ was boiled in $10 \mathrm{~cm}^{3}$ of water in separates test tubes and then filtered. A few drops of $5 \%$ Iron (III) chloride were added a formation of brownish colour indicates the presence of tannin (Edeoga, 2000). 
Special Conference Edition, November, 2019 Screening for Activity of the Plant Extracts Test Organisms

The strains of Staphylococcus aureus, Escherichia coli, Pseudomonas aeruginosa and Streptococcus spp. were used for antibacterial activities. These were pure isolates obtained from Microbiology Unit, Usmanu Danfodiyo University Teaching Hospital Sokoto.

\section{Preparation of Paper Disc for Sensitivity}

Test

Whatman filter papers 1 (110 $\mathrm{mm}$ diameter) were placed in different concentrations of the extracts $30 \mathrm{mg} / \mathrm{cm}^{3}, 60 \mathrm{mg} / \mathrm{cm}^{3}, 90 \mathrm{mg} / \mathrm{cm}^{3}$ and $120 \mathrm{mg} / \mathrm{cm}^{3}$ for 24 hours. The adsorbed paper discs were dried.

\section{Anti-Bacterial Activity Testing}

The disc diffusion method was used to determine the antibacterial activity of the extracts. The cultured organism ( $S$. aureus, $P$. aeruginosa, E. coli and Streptococcus spp) were inoculated into the medium in a separate plate. The paper discs prepared earlier were sufficiently poured unto the plates containing the bacterial cultured using sterilized forceps dipped in alcohol, flamed and cooled. The discs were placed on each spaced $15 \mathrm{~cm}$ from each other to prevent the resulting zones of inhibition from overlapping. The plates were incubated at a temperature of $37^{\circ} \mathrm{C}$ for 24 hours before being examined for zone of inhibitions which were measured with a transparent ruler (Duguid, 1989).

\section{RESULTS AND DISCUSSION}

\section{Preliminary Phytochemical Screening}

The phytochemical constituents of methanolic extract of $M$. azedarach stem bark showed the presence of all the secondary metabolites tested for. The results are presented in Table 1.

Table 1: Phytochemical constituents of methanolic extract of $M$. azedarach stem bark.

\begin{tabular}{lc}
\hline Phytochemicals & Methanol \\
\hline Alkaloids & +++ \\
Cardiac glycosides & + \\
Flavonoids & +++ \\
Saponins & ++ \\
Steroids & + \\
Tannins & ++ \\
Terpenoids & + \\
\hline
\end{tabular}

Key: +++ Presence in high intensity, ++ Moderate presence of the compound,

+ Presence in low intensity

Antibacterial Characteristics of the Methanol Stem Bark Extract

The Antibacterial Characteristics of the Methanol

Stem Bark Extract showed various degree of the zone of inhibitions at different concentrations. The results are presented in Table 2

Table 2. Antibacterial activity of Melia azedarach Methanol extract.

\begin{tabular}{lcccc}
\hline Extract conc. & \multicolumn{2}{c}{ Zone of inhibition $\mathbf{( m m )}$} \\
\hline $\mathbf{( m g / \mathbf { c m } ^ { 3 } )}$ & S. aureus & P. aeruginosa & E. coli & Streptococcus \\
spp & & & & 7.0 \\
30 & 8.5 & 10 & 8.5 & 8 \\
60 & 9.5 & 10 & 9 & 9 \\
90 & 9.5 & 11 & 10 & 11 \\
120 & 11 & 12 & 11 & \\
\hline
\end{tabular}

\section{DISCUSSION}

The Phytochemical analysis of the methanol extract of $M$. azedarach stem bark revealed the presence of alkaloids, cardiac glycosides saponins, flavonoids, saponins, steroids, tannins, and the terpenoids (Table 1). James et al. (2007) reported that tannins and flavonoids have biological activities that are of benefit in preventing and management of many infections. Erah et al. (1996) reported that antimicrobial activities are associated with the presence of tannins and flavonoids. Alkaloids are well known for their wide pharmacological activities ranging from antibacterial and antifungal activities (Trease and Evan, 1989). Cardiac glycoside, comprises of glycosides that exert a cardiatonic action and therefore are used to improve blood circulation and heart function in congestive heart failure (El-olemy et al., 1994; Umar et al., 2011). 
Special Conference Edition, November, 2019 Wakirwa et al. (2013) also reported the presence of saponins in the root and leaves of Melia azedarach. Methanolic extracts of Melia azedarach (stem Bark) indicates that the alcoholic extracts of these plants could be a possible source of new herbal medicines to treat infectious diseases.

The methanol root extract showed activity against all tested organisms. The higher diameter of zone of inhibition of $12 \mathrm{~mm}$ was observed against $P$. aeruginosa followed by $S$. aureus, E. coli and Streptococcus spp which showed diameter of zone of inhibition of $11 \mathrm{~mm}$ each at concentrations of $120 \mathrm{mg} / \mathrm{cm}^{3}$ (Table 2). Less activity of $7.0 \mathrm{~mm}$ was observed at a concentration of $30 \mathrm{mg} / \mathrm{cm}^{3}$ against Streptococcus spp. This also showed that the activities of the extract is concentration dependent. The plant under study is therefore an effective antibacterial agent. The inhibitory activity proved the potential application of the plant in the treatment of microbial infections. The extract of this plant showed antibacterial activity against Gram positive and Gram negative bacteria. This is in line with the findings of Abdul (2011), where moderate zone of

\section{REFERENCES}

Abbasi, A.M., Khan, M.A., Ahmad, M., Zafar, M., Khan, H., Muhammad, N., and Sultana, S. (2011). Medicinal plant used for treatment of jaundice and hepatitis based on socio-economic documentation. Africa Journal of Biotechnology. 8(8): $1643-1650$.

Abdul, K.M., Hanitta, K.P. and Hanitta, M.A. (2011). Evaluation of antibacterial activity of Medicinal plants on Fish Pathogen. Aeromonas hydrophila Journal of Research Biology.1:1-5.

Ayoola, G.A, Coker, H.A.B., Adesegun, S.A., Adepoju-Bello, A.A., Obaweya, K., Ezennia, E.C. and Atangbayila, T.O. (2008) Phytochemical screening and antioxidant activities of some selected medicinal plants used for malaria therapy in southwestern Nigeria. Tropical Journal of Pharmaceutical Research. 7(3): 1019-1024.

Bharat, P., Sulav, R. and Sagar, R. (2015). Phytochemical screening, Antimicrobial and Antioxidant activities of Methanol extract of Melia azedarach Linn leaves; World Journal of Pharmacy and Pharmaceutical Science 4(7): 15621575.

Duguid, J.P., Mamion, B.P. and Swain, R.H.A. (1978). Staphylococcus: In Mackie and Mc Cartney Medical Microbiology $13^{\text {th }}$ inhibition of $11 \mathrm{~mm}$ and $8 \mathrm{~mm}$ was observed against $S$. torvum and $C$. longa respectively

\section{CONCLUSION}

Crude methanolic extract of Melia azedarach contains secondary metabolites with relatively high inhibitory power on both Gram positive and Gram negative bacteria, therefore the stem bark of Melia azedarach contain antibacterial agents and nutrients. The result of the present study suggests that the Melia azedarach can be used as a source of antimicrobial for pharmacological preparations.

\section{Acknowledgement}

The authors are sincerely grateful to Prof. S.M. Dangoggo, Prof. L.G Hassan and Dr. Mishelia, E. of Usmanu Danfodiyo University, Sokoto for their encouragement and support. The authors also would like to appreciate Mal. Abdulaziz, Herbarium unit, Biological Science Department, Usmanu Danfodiyo University, Sokoto, Nigeria for helping us in identification of plants. We also wish to acknowledge the support of the management of Kashim Ibrahim College of Education Maiduguri, Borno State Nigeria.

Edition. Longman group Ltd. Uk., Pp 236-244.

Edeoga, H.A., Okwe, D.E. and Mbaebie, B.O. (2000). Phytochemical constituent of some Nigerian Medicinal plants. Africa Journal of Biotechnology. 4(7): 685-688.

El-olemy, M.M., Al-muhadi, F.J. and Afifi, A.A. (1994). Experimental phytochemicals. A Laboratory manual. King Saud University Press. Jedda. Pp 7-67.

Erah, P.O., Osuide, G.E, and Omogbai, E.K.I. (1996). Hypocaemic effect of the extract Solentemon Monostachys ( $p$ Beauv) leaves. Journal of West Africa. Pharmacy. 10: 21-27

Gahukar, R.T. (2011). Use of Neem in Plant Protection. $1^{\text {st }}$ Ed. Agri-Horticultural Publishing House Nagpur India. Pp 55.

Harborne, J.B. (1998). Phytochemical Methods: A Guide to Modern technique of Plant Analysis. $3^{\text {rd }}$ edition. London, England. Chapman and Hall. Pp: 114-118.

James, D.B., Abu, E.A., Wurochekke, A.U. and Ori, G.N. (2007). Phytochemical and antibacterial investigation of aqueous and methanolic extract of Ximenia americana. Journal of Medical Science. 7(2):284-288.

Ji, H.F., Li, X.J. and Zhang, H.Y. (2009). Natural products and drug discovery. EMBO reports. 10 (3): 194-200. 
Special Conference Edition, November, 2019

Makkar, H.P.S. and Beckar, K. (1993). Vanilin$\mathrm{HCl}$ method for condensed tannins: Effect of organic solvents used for extraction of tannins. Journal of Chemical Ecology. 19 (4): 613 - 621.

Ramya, S., Jepachanderamohan, P.J., Alaguchamy, N., Kalayanasundaram, M. and Jayakumararaj, R. (2009); In vitro antibacterial Prosprotective of crude leaf extracts of Melia azedarach Linn against selected bacterial strains, Ethnobotanic Leaflets 13: 254-258.

Sureh, K.S.V. and Mishra, S. H. (2008). Hepaprotective effect of Pergularia daemia (Forsk) ethanol extract and its function. India Journal of experimental Biology. 46:447-452.

Trease, G.E. and Evans, W.C. (1989) Pharmacognocy. $13^{\text {th }}$ Ed., Brailliere Tindall, Macmillan Publishers, London. Pp 176-180.
Umar, K.J., Rabe, A.B., Na' ala, M., Bello, M., Ibrahim, M.L. and Garba, M. (2011). Antibacterial and phytochemical screening of methanolic extract of Celosia Leptostachya Benth Leaves on some selected clinical isolates. Journal of Medicinal Plants Research. 5(28):6473-6476.

Wakirwa, J. H., Ibrahim, P. and Madu, S. (2013). Phytochemical screening and vitro antibacterial analysis of the ethanol stem bark extract of Jatrophy curcas L. International Resource Journal of Pharmacy. 4(3): 97.

Zhang, (2005). A Comparison of Medical Management with Misoprostol and surgical Management for early pregnancy failure. England Journal of Medical Science.353:761-769. 